Most workers agree that the cell that gives rise to colonies in the agar colony system is equivalent to the granulopoietic stem cell. " The formation of colonies, however, requires the activation of this cell and the serial proliferation of its progeny, and we cannot distinguish from our data whether quinine had a toxic effect on either or both of these mechanisms.

Our results encourage the further use of the marrow culture system for trying to identify in vitro drugs responsible for agranulocytosis in particular patients. At present only watersoluble drugs can be tested, which will remain a problem until non-toxic solvents for insoluble drugs are developed. A further obvious but none the less important precaution is not to test parenteral preparations containing preservatives, which are well known to be inhibitory in the marrow culture system.

\section{References}

${ }^{1}$ Lind, D E, Levi, I A, and Vincent, P C, British Medical fournal, 1973, 1, 458

${ }^{2}$ Howell, A, Andrews, T M, and Watts, R W E, Quarterly fournal of Medicine, 1973, 42, 834.

${ }^{3}$ Howell, A, et al, Clinical Science and Molecular Medicine, 1974, 46, 619.

4 Ratzan, R J, Moore, M A S, and Yunis, A A, Blood, 1974, 43, 363.

5 Hartl, P W, in Blood Disorders Due to Drugs and Other Agents, ed Ronald H Girdwood, p 147. Amsterdam, Excerpta Medica, 1973.

'Robinson, W A, and Pike, B L, in Hemopoietic Cellular Proliferation, ed F Stohlman jun, p 249, New York, Grune and Stratton, 1970.

Martindale: The Extra Pharmacopoeia, 26th ed, pp 439 and 1567. London, Pharmaceutical Press, 1972.

${ }^{8}$ Rickard, K A, et al, in Hemopoietic Cellular Proliferation, ed F Stohlman jun, p 238. New York, Grune and Stratton, 1970.

(Accepted 31 December 1976)

\title{
Metronidazole in prevention and treatment of bacteroides infections in elective colonic surgery
}

\author{
A T WILLIS, I R FERGUSON, P H JONES, K D PHILLIPS, P V TEARLE, R V FIDDIAN, \\ D F GRAHAM, D H C HARLAND, D F R HUGHES, D KNIGHT, W M MEE, N PASHBY, \\ R L ROTHWELL-JACKSON, A K SACHDEVA, IRENE SUTCH, CAROL KILBEY, \\ DEBORAH EDWARDS
}

British Medical fournal, 1977, 1, 607-610

\section{Summary}

A double-blind randomised trial was carried out among 46 patients undergoing elective colonic surgery; 27 patients received prophylactic metronidazole and 19 received placebo. Anaerobic infections did not develop in any of the metronidazole-treated patients, but did develop in $11(58 \%)$ of 19 controls who were subsequently successfully treated with metronidazole.

\section{Introduction}

Gastrointestinal surgery is associated with a high incidence of postoperative sepsis due to contamination of the field of operation by organisms from the intestine. An incidence of serious sepsis in excess of $50^{\circ}{ }^{\circ}$ is common. ${ }^{1-4}$

Luton and Dunstable Hospital, Luton LU4 0DZ

A T WILLIS, MD, FRACP, consultant microbiologist

I R FERGUSON, MB, DIPBACT, assistant bacteriologist

P H JONES, MB, MSC, trainee bacteriologist

K D PHILLIPS, BSC, senior scientific officer

P V TEARI.E, FIMLS, technician

R V FIDDIAN, FRCS, $\mathrm{MCH}$, consultant surgeon

D F GRAHAM, FRCS, surgical registrar

D H C HARLAND, FRCS, consultant surgeon

D F R HUGHES, FRCS, surgical registrar

D KNIGHT, FRACS, surgical registrar

W M MEE, FRCS, consultant surgeon

N PASHBY, MB, surgical registrar

R L ROTHWELL-JACKSON, FRCS, MCH, consultant surgeon

A K SACHDEVA, FRCS(ED), surgical registrar

IRENE SUTCH, MPS, district pharmaceutical officer

CAROL KILBEY, BPHARM, MPS, staff pharmacist

DEBORAH EDWARDS, BPHARM, MPS, staff pharmacist
Although the value of preoperative mechanical emptying of the bowel is not disputed, the use of prophylactic antibiotics in the preparation of patients for elective bowel surgery has remained controversial. ${ }^{5-10}$ Most studies of antibiotic prophylaxis have been concerned with control of infections due to aerobic bacteria, against which even prolonged courses of systemic antibiotics have frequently proved ineffective. Clearly the rational use of prophylactic antibiotics in colonic surgery requires an understanding of the bacterial flora encountered during surgery and of the sensitivity of the bacteria to various antibiotics.

There has been an increasing awareness of the importance of non-sporing anaerobes as a major cause of sepsis after surgery of the gastrointestinal tract. ${ }^{71-13}$ Indeed, recent studies ${ }^{13-15}$ which made use of the specific bactericidal activity of metronidazole against anaerobes in the prevention of postoperative sepsis after gastrointestinal and gynaecological surgery, strongly supported the view that aerobic bacteria are usually of only secondary importance in these clinical settings.

We report here the clinical and bacteriological findings of a double-blind trial of the value of metronidazole in the prophylaxis and treatment of sepsis after colonic surgery.

\section{Patients and methods}

All patients admitted to the Luton and Dunstable Hospital for elective colonic surgery during a 9-month period were admitted to the trial, provided that there was no recent history of antibiotic or metronidazole treatment. The study was a double-blind trial using active and placebo suppositories and oral tablets. Patients were randomly allocated to metronidazole and placebo groups.

Initially 64 patients were admitted to the study; 35 received prophylactic metronidazole and 29 were controls. During the study period 18 patients ceased to qualify for the trial-no colonic surgery was undertaken in seven, other antibiotic treatment was begun in eight, and the double-blind prophylaxis was incomplete in three patients. We therefore analysed 46 patients, 27 of whom received metronidazole (table I). Most operations were for malignant disease 
(21 among metronidazole patients and 15 among controls). The remaining 10 patients suffered from diverticular disease (two in each group), Crohn's disease (one in each group), ulcerative colitis (one in each group), and perforation of large bowel (two in metronidazole group). Patients in the two groups were moderately well-matched for sex, age, underlying pathology, operative procedure, and state of bowel at operation.

\section{CLINICAL MANAGEMENT}

Before operation-All patients were prepared with mechanical evacuation of the bowel. Twenty-four hours preoperatively an oral dose of metronidazole $1 \mathrm{~g}$ or placebo was given, followed by one 200-mg tablet 8-hourly until preoperative starvation; this regimen aimed at achieving early and adequate blood and tissue concentrations. As part of the preoperative medication each patient was given a single intramuscular injection of $80 \mathrm{mg}$ gentamicin, and a Witepsol-base suppository rectally that contained either $1 \mathrm{~g}$ of metronidazole or placebo. ${ }^{13} 15 \mathrm{~A}$ sample of blood for metronidazole assay was collected during induction of anaesthesia.

TABLE I-Features of 46 patients and controls who underwent elective colonic surgery

\begin{tabular}{|c|c|c|}
\hline & Metronidazole & Placebo \\
\hline $\begin{array}{c}\text { Sex: } \\
\underset{\mathrm{M}}{\mathrm{F}}\end{array}$ & $\begin{array}{l}14 \\
13\end{array}$ & $\begin{array}{r}12 \\
7\end{array}$ \\
\hline $\begin{array}{l}\text { Age: } \\
<41 \\
41-50 \\
51-60 \\
61-70 \\
>70\end{array}$ & $\begin{array}{r}3 \\
2 \\
6 \\
6 \\
10\end{array}$ & $\begin{array}{l}1 \\
4 \\
1 \\
8 \\
5\end{array}$ \\
\hline $\begin{array}{l}\text { Operation: } \\
\text { Anterior resection } \\
\mathrm{R} \text { hemicolectomy } \\
\text { L hemicolectomy } \\
\text { Abdominoperineal resection } \\
\text { Others }\end{array}$ & $\begin{array}{r}7 \\
2 \\
2 \\
4 \\
12\end{array}$ & $\begin{array}{l}7 \\
3 \\
1 \\
4 \\
4\end{array}$ \\
\hline $\begin{array}{l}\text { State of bowel at operation: } \\
\text { Loaded } \\
\text { No soiling } \\
\text { Soiling }\end{array}$ & 2 & $\begin{array}{l}1 \\
1\end{array}$ \\
\hline $\begin{array}{l}\text { Empty } \\
\text { No soiling } \\
\text { Soiling }\end{array}$ & $\begin{array}{r}15 \\
5\end{array}$ & $\begin{array}{r}16 \\
1\end{array}$ \\
\hline
\end{tabular}

At operation-Clearly, no uniform technique for colonic surgery was possible. The four surgical teams taking part in the study used a routine preoperative skin preparation. No other antibacterial agents were used during surgery. After operation the surgeon recorded details of operative technique and clinical findings on a form.

After operation-Patients continued to receive metronidazole or placebo prophylaxis until the end of the seventh postoperative day. With few exceptions each patient received one suppository every eight hours until oral feeding began, when 200 -mg tablets of metronidazole or placebo were given three times daily. If suppositories could not be administered rectally, they were administered per colostomy. Two patients with ileostomy who tended to reject suppositories were successfully given metronidazole or placebo via a nasogastric tube as a suspension of the powder ( $200 \mathrm{mg} 8$-hourly). Satisfactory blood concentrations of metronidazole (of the order of $2.5 \mathrm{\mu g} / \mathrm{ml}$ after 1 hour) were achieved, although routine aspiration of the stomach was continued at hourly intervals. No other antimicrobial agents were used. A single sample of blood for metronidazole assay was collected during the first three postoperative days. Careful daily clinical records were kept of the patients' progress, special attention being paid to any evidence of clinical infection. Additional specimens for bacteriological study (urine, sputum, surgical wound swabs, etc) were collected as indicated by the patients' clinical condition. When a patient developed proved anaerobic sepsis we broke the double-blind trial code to find out whether the patient was receiving placebo or metronidazole.

Post-surgical sepsis-Only clinical evidence was used to classify patients as infected, but findings were confirmed by microbiology when they had been clinically identified. Specimens of pus, wound exudate and so on were examined and assessed by conventional aerobic and anaerobic methods. Other postoperative specimens such as urine and sputum were collected and examined as appropriate.

\section{Results}

INCIDENCE OF POSTOPERATIVE INFECTION CAUSED BY ANAEROBES

Within both groups of patients there were several infections due exclusively to aerobic organisms (Escherichia coli and related Enterobacteriaceae, enterococci, and Staphylococcus aureus) (table II). Aerobic wound infections developed in five patients (four test patients and one control); these differences are not statistically significant. Postsurgical sepsis due to aerobic organisms was always superficial, mild, and never foul-smelling; only one of these five infections (a metronidazole-treated patient) required antimicrobial therapy.

Anaerobic infections did not develop in any of the 27 patients who received prophylactic metronidazole, but bacteriologically confirmed clinical anerobic infections developed in $11\left(58^{\circ}{ }_{0}\right)$ of the 19 controls (table II). All of these patients were feverish and ill, and there were foul-smelling discharges from their wounds, usually copious and without evidence of superficial inflammation. Although exploration was not always undertaken, all of these infections were judged to be deep-seated and due to non-sporing anaerobes. In one patient there was breakdown of the perineal wound, in another abdominal wound dehiscence, and a third patient developed severe Bacteroides fragilis bacteraemia. Among the 11 patients who developed postoperative anaerobic infections reference to the double-blind trial code showed that none of them was receiving prophylactic metronidazole, and the drug was then given therapeutically, along the general lines outlined in the prophylactic schedule; gentamicin was sometimes also given.

TABLE II-Postoperative infections among 46 patients and controls after colonic surgery. Figures are numbers of patients

\begin{tabular}{|c|c|c|}
\hline Group & Not infected & Infected \\
\hline $\begin{array}{l}\text { Anaerobic infections: } \\
\text { Metronidazole } \\
\text { Controls }\end{array}$ & $\begin{array}{rr}27 & \\
& \\
& x^{2}=\end{array}$ & $005^{11}$ \\
\hline $\begin{array}{l}\text { Aerobic infections: } \\
\text { Metronidazole } \\
\text { Controls }\end{array}$ & \multicolumn{2}{|c|}{$18 \quad x^{2}=2.27 ; P<0.25$} \\
\hline
\end{tabular}

In all cases the temperature settled within 12-24 hours, with subsequent cessation of discharge and uneventful recovery from the infection.

\section{CLINICAL PROGRESS}

It is relevant here to refer briefly to two patients whose clinical progress exemplifies that of the metronidazole group.

Case 1-A bronchitic 61-year-old man with extensive obstructing carcinoma at the level of the rectosigmoid junction was admitted to the double-blind trial and received active metronidazole prophylaxis. During abdominoperineal resection of the rectum there was contamination of the field of operation with liquid faeces from the lower bowel. The pelvis and perineum were washed out with sterile water and mercuric chloride (which led to his exclusion from the trial), and the perineum closed with suction drainage. Twenty-four hours postoperatively the patient developed lobar pneumonia that was treated successfully with ampicillin - this, too, automatically excluded him from the trial. There was no evidence of postoperative surgical sepsis, however, and the perineum and the wound healed by first intention.

Case 2-A 64-year-old man presented with a five-month history and a mass in the rectosigmoid region palpable from above and below. Barium sulphate could not be coerced past the lesion, which was thought to be a colonic neoplasm. He was admitted to the double-blind trial and received metronidazole prophylaxis. At exploratory operation the pelvic mass was found to involve the bladder, rectosigmoid colon, and caecum, and since there was extensive inflammation and a loaded colon, a terminal left iliac colostomy was raised and the distal bowel brought through the lower wound as a mucous fistula. Two weeks postoperatively when the trial protocol had been completed necrosis of the colostomy developed from faecal impaction, and reoperation was necessary. Combined metronidazole and gentamicin prophylaxis was given. At operation there were free faeces in the abdominal wall next to the colostomy, in the adjacent peritoneal cavity, and in the main abdominal wound. Extensive saline lavage was carried out, the rectum excised and oversewn as in a Hartmann procedure, and a new colostomy formed from the left colon; metronidazole and gentamicin 
were continued postoperatively during which time the patient's condition improved rapidly. Recovery was uninterrupted and the wound healed without postoperative sepsis.

\section{TYPE OF INFECTION AND STATE OF BOWEL AT OPERATION}

There was no clear relation between the incidence of aerobic or anaerobic infection and the state of the bowel and presence or absence of faecal soiling. Of the 11 anaerobic infections in the control group, 10 occurred in patients whose large bowel was empty at operation and in whom no faecal soiling was noted; the other anaerobic infection developed in a patient in whom surgically induced faecal soiling occurred from a loaded large bowel (table I). Of the five patients who developed aerobic wound infections, three occurred in patients with a clean bowel without soiling (two metronidazole patients, one control), one in a metronidazole patient with a clean bowel but in whom surgically induced faecal soiling occurred from a loaded large bowel.

Bacteriology-In common with the experience of others, almost all of the 11 patients with intra-abdominal anaerobic infections yielded both aerobic and anaerobic bacteria. In one patient $B$ fragilis was isolated in pure culture from discharging pus, and in another there was $B$ fragilis bacteraemia. In five patients obligate anaerobes predominated, while in the other four patients in whom anaerobes were judged clinically and bacteriologically to be the major pathogenic organisms, both groups were present in about equal numbers. The commonest anaerobes isolated were $B$ fragilis (nine patients) and $B$ melaninogenicus (five patients), while the commonest aerobic bacteria were $E$ coli and related coliform bacteria (six patients) and enterococci (six patients) Pus from three of five patients from whom $B$ melaninogenicus was subsequently isolated showed red fluorescence in ultraviolet light, and gas-liquid chromatography of pus from all six patients from whom adequate samples were submitted showed the presence of multiple volatile fatty acids typical of an anaerobic infection. ${ }^{16}$

Metronidazole assays were kindly performed by May and Baker by polarography on preoperative and postoperative blood samples collected from patients in the test and control groups. Metronidazole was not present in blood samples from patients receiving placebo. Among test patients the mean preoperative metronidazole concentration was $65.5 \mu \mathrm{mol} / \mathrm{l}(11.3 \mu \mathrm{g} / \mathrm{ml}$ ) (range $5.8-156 \mu \mathrm{mol} / \mathrm{l} ; 1-27$ $\mu \mathrm{g} / \mathrm{ml}$ ), and the mean postoperative concentration was $88.7 \mu \mathrm{mol} / \mathrm{l}$ $(15 \cdot 3 \mu \mathrm{g} / \mathrm{ml}$ ) (range $17 \cdot 4-203 \cdot 0 \mu \mathrm{mol} / 1 ; 3-35 \mu \mathrm{g} / \mathrm{ml}$ ).

\section{Discussion}

Although relatively few patients were studied in this trial, our results show clearly that a bactericidal concentration of metronidazole in the blood sustained during and after operation greatly reduces the frequency of postoperative infection. All 11 postoperative anaerobic infections developed in patients who received placebo only. Since 19 colonic operations were performed in the control group and 27 in the metronidazole group, there is no doubt that metronidazole was an effective prophylactic $\left(\chi^{2}\right.$ with Yates's correction $\left.=17.8 ; \mathrm{P}<0.0005\right)$. Even when all surgical infections are taken into account, including those due to aerobic infections, upon the incidence of which metronidazole can have no direct effect, the difference in the infection rates remains highly significant $\left(\chi^{2}=10 \cdot 8 ; P<0.0001\right)$.

The absolute inactivity of metronidazole against aerobic bacteria, and its remarkable efficacy in reducing the incidence of postsurgical sepsis clearly implies that most of the infections that complicated colonic surgery had an anaerobic bacterial aetiology. Confirmation of this was provided by the bacteriological findings among those control patients who developed clinical postoperative infections. Conclusions of this sort cannot be drawn from similar prophylactic studies in which a single broadspectrum drug such as a cephalosporin, or mixtures of drugs such as gentamicin and lincomycin have been used. Nor can they be inferred from studies of chemical antiseptics such as povidone-iodine, which are usually unselective, "total" bactericidal agents. We believe that antimicrobial prophylaxis of endogenously derived anerobic infections requires the presence of an appropriate drug circulating in the patients' blood at the time of surgery. This requirement cannot be met by the use of antiseptics.
Earlier investigations of metronidazole treatment ${ }^{13-15}$ used the prophylactic approach in order to determine the possible therapeutic value of the drug in anaerobic sepsis. It soon became clear that metronidazole prevented the development of most severe postoperative sepsis, a finding that has been substantiated in the present study. Moreover, the remarkable difference in the anaerobic sepsis rates between the two groups of patients (11 of 19 control patients; none of 27 test patients) is similar to that reported by Goldring et $a l,{ }^{7}$ who used kanamycin and metronidazole for the preoperative "sterilisation" of the gut.

Although it is beyond our competence to discuss the contemporary philosophy of antibiotic prophylaxis, it is difficult to reconcile its theoretical disadvantages with the practical reality that anaerobic infection is a common and often life-threatening complication of colonic surgery. In our view, failure to employ thoughtful preventive treatment is as difficult to justify as the use of indiscriminate "shot-gun" prophylaxis.

We were not primarily concerned in the present study to reduce the incidence of sepsis due to aerobic organisms. Gentamicin, which was given once preoperatively to replace aminoglycoside "sterilisation" of the bowel, may be regarded as "short-term prophylaxis" directed against these organisms; in this context it was unsuccessful. Whether or not gentamicin played any important part in combination with metronidazole in preventing the development of anaerobic infection must remain speculative. Nevertheless, our experience in the prevention and treatment of anaerobic infections with metronidazole in various similar clinical settings suggests that its activity alone is sufficient to eliminate anaerobic sepsis. Consequently we believe that gentamicin could have been safely omitted.

The fairly conventional dosage schedules of metronidazole used in these studies were chosen arbitrarily, since we wished only to obtain adequate blood metronidazole concentrations, no close attention being paid to the pharmacokinetics of the drug. These schedules were probably more than adequate, and in future it should be possible to reduce both the dosage and the duration of treatment without adversely affecting the protection afforded. Toxic or other untoward effects were never encountered. Although use of the rectal route is regarded as a clinical novelty by some, administration was easy for the nursing staff and acceptable to patients.

Since the completion of this study metronidazole prophylaxis has been used routinely in our hospital for all patients undergoing colonic surgery. This policy of routine prophylaxis would need to be reconsidered if metronidazole resistance was shown to develop in vivo; no such acquired resistance has yet been encountered. Moreover, prolonged efforts by one of us (IRF) have failed altogether to induce stable resistance in vitro to metronidazole among strains of $B$ fragilis. Since aerobic bacteria are all inherently resistant to metronidazole, these organisms do not impose the sorts of constraints upon its prophylactic use that may apply to broad-spectrum drugs such as lincomycin and beta-lactam antibiotics.

In all our infected patients the clinical and microbiological response to metronidazole was dramatic. Within $12-24$ hours the temperature and pulse rate had usually returned to normal, the patient felt and looked better, and there was clear evidence of resolution of any cellulitis. There was a strikingly rapid disappearance of anaerobic bacteria from pathological discharges, which ceased to be purulent and offensive and quickly subsided.

Whatever views may be held about the prophylactic as opposed to the therapeutic use of metronidazole, our experience adds considerable weight to the proposal that metronidazole should now be regarded as the drug of choice for the prevention of these infections and for the treatment of those non-clostridial anaerobic infections that require antimicrobial therapy.

We thank May and Baker for providing preparations of metronidazole and assaying serum metronidazole. We are indebted to our anaesthetic colleagues, to the junior surgical staff, and to the surgical nursing staff for their willing co-operation, and to Mrs Janet Holt for secretarial assistance. 
Requests for reprints should be addressed to A T Willis, Public Health Laboratory, Luton and Dunstable Hospital, Lewsey Road, Luton LU4 ODZ.

\author{
References \\ ${ }^{1}$ Everett, M T, Brogan, T D, and Nettleton, J, British fournal of Surgery, \\ 1969, 56, 679 . \\ ${ }^{2}$ Jackson, D W, Pollock, A V, and Tindal, D S, British fournal of Surgery, \\ $1971,58,340$. \\ 3 Davidson, A I G, Smith, G, and Smylie, H G, British fournal of Surgery, \\ $1971,58,326$. \\ 4 Burton, R C, British fournal of Surgery, 1973, 60, 363.
}

${ }^{5}$ Nichols, R L, et al, Annals of Surgery, 1973, 178, 453.

${ }^{6}$ Stokes, E J, et al, British fournal of Surgery, 1974, 61, 739.

7 Goldring, J, et al, Lancet, 1975, 2, 997.

${ }^{8}$ Griffiths, D A, et al, Lancet, 1976, 2, 325.

${ }^{9}$ Keighley, M R B, et al, British fournal of Surgery, 1976, 63, 538

${ }^{10}$ Roy, A D, fournal of Antimicrobial Chemotherapy, 1975, 2, 233.

${ }^{11}$ Leigh, D A, Simmons, K, and Norman, E, fournal of Clinical Pathology, 1974, 27, 997 .

12 Leigh, D A, British fournal of Surgery, 1975, 62, 375.

${ }^{3}$ Willis, A T, et al, British Medical fournal, 1976, 1, 318.

${ }^{14}$ Willis, A T, et al, Lancet, 1974, 2, 1540.

${ }_{15}$ Willis, A T, et al, fournal of Antimicrobial Chemotherapy, 1975, 1, 393.

${ }^{16}$ Phillips, K D, Tearle, P V, and Willis, A T, fournal of Clinical Pathology, $1976,29,428$.

(Accepted 31 December 1977)

\title{
Antiribonucleoprotein antibodies in connective tissue diseases: estimation by counterimmunoelectrophoresis
}

\author{
BARRY BRESNIHAN, CHRISTOPHER BUNN, MICHAEL L SNAITH, GRAHAM R V HUGHES
}

British Medical fournal, 1977, 1, 610-611

\section{Summary \\ One hundred and seventy-two patients with various connective tissue diseases were investigated for the presence of serum antibodies to extractable nuclear antigen (ENA) and its major components, ribonucleo- protein (RNP) and Sm antigen. The counter-immuno- electrophoresis assay allowed independent detection and measurement of antibodies to the different components. All 13 patients with mixed connective tissue disease (MCTD) had anti-RNP antibody in high titres, $16 \%$ of patients with systemic lupus erythematosus (SLE) had low titres, and none of the patients with scleroderma had anti-RNP antibody. MCTD seems to be more benign than either SLE or scleroderma. The counterimmunoelectro- phoresis assay is a simple and sensitive technique for confirming the diagnosis.}

\section{Introduction}

The classification and diagnosis of the connective tissue diseases have been helped by the identification of immunological markers such as circulating antibodies to $\mathrm{DNA}^{1}$ and extractable nuclear antigen (ENA)." Anti-ENA was found in high titres in a group of patients with "overlap" symptoms, who had features of scleroderma, polymyositis, and systemic lupus erythematosus (SLE). ${ }^{3}$ The condition has been called mixed connective tissue disease (MCTD) and was found to have a good prognosis, with renal disease being distinctly uncommon. With the more

\footnotetext{
Department of Medicine, Royal Postgraduate Medical School, Hammersmith Hospital, London W12 0HS

BARRY BRESNIHAN, MB, MRCP, senior registrar

CHRISTOPHER BUNN, medical technician

GRAHAM R V HUGHES, MD, MRCP, consultant physician

Department of Rheumatology, University College Hospital, London WC1

MICHAEL L SNAITH, MD, MRCP, consultant physician
}

widespread measurement of anti-ENA antibodies, it is becoming clear that MCTD may be not only a distinct condition but also one of the more common connective tissue diseases. ${ }^{4}$

ENA is made up of two major components: ribonucleoprotein (RNP), which is sensitive to enzymatic digestion by ribonuclease and a non-nucleic acid glycoprotein, known as Sm antigen, which is not sensitive to ribonuclease digestion. Most studies of anti-ENA antibodies have used either a passive diffusion assay $^{i-7}$ or a haemagglutination technique, ${ }^{1}{ }^{2} 89$ but the former lacks sensitivity and the latter gives confusing results when antibody to RNP and Sm antigen are both present in the same serum. Recently Kurata and Tan used counterimmunoelectrophoresis (CIE), which clearly identifies antibodies to the individual components of ENA. ${ }^{10}$ We therefore used CIE to investigate a large series of patients with various connective tissue disorders.

\section{Patients and methods}

Sera were obtained from 172 patients seen at Hammersmith Hospital (table I). The clinical features of the patients diagnosed as having MCTD are shown in table II. All patients with SLE fulfilled at least four of the criteria of the American Rheumatism Association and had antibodies to double-stranded DNA, detected by the Farr technique. All patients with scleroderma had longstanding disease.

Counterimmunoelectrophoresis-ENA (Pel-Freeze Biologicals Inc, Rogers, Arkansas) was the gift of Dr Eng Tan, La Jolla, California. It was dissolved in $0.9-\mathrm{M} \mathrm{NaCl}$ by stirring overnight at $4^{\circ} \mathrm{C}$. Glass plates were layered with $1^{\circ}$ ", agarose in barbitone buffer, and wells, $3 \mathrm{~mm}$ in diameter, were cut in pairs with the centres $6-\mathrm{mm}$ apart. The anodal well was filled with $8: 2$ l of undiluted serum, and a current of

TABLE I-Prevalence of anti-ENA antibodies in patients with connective tissue diseases

\begin{tabular}{l|c|c|c}
\hline & $\begin{array}{c}\text { No of } \\
\text { patients }\end{array}$ & $\begin{array}{c}\text { No with } \\
\text { anti-ENA } \\
\text { antibody }\end{array}$ & $\begin{array}{c}\text { No with } \\
\text { anti-RNP } \\
\text { antibody }\end{array}$ \\
\hline $\begin{array}{l}\text { Normal subjects } \\
\text { Patients with: }\end{array}$ & 35 & 0 & 0 \\
Mixed connective tissue diseases & 13 & 13 & 13 \\
Systemic lupus erythematosus & 90 & 24 & 17 \\
Polymyositis & 13 & 0 & 0 \\
Scleroderma & 32 & 0 & 0 \\
Rheumatoid arthritis & 24 & 0 & 0 \\
\hline
\end{tabular}

